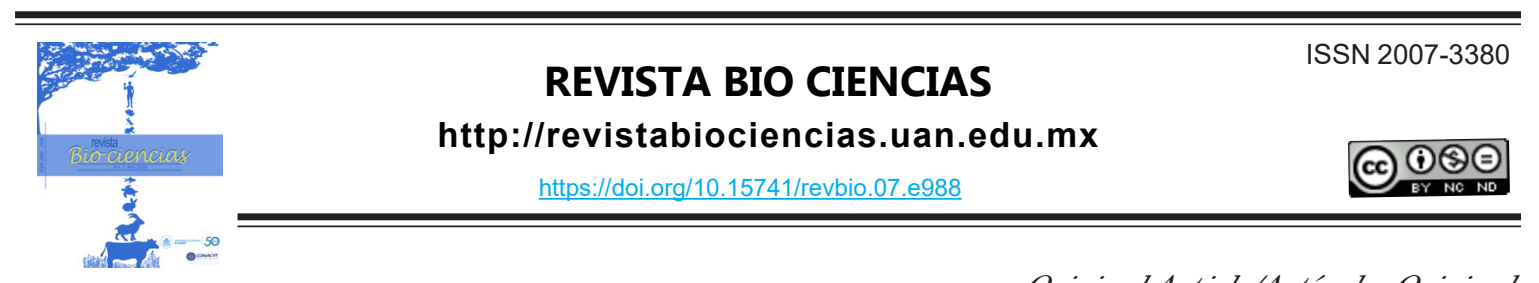

Original ArticlelArtículo Original

\title{
Morphology and potential antibacterial capability of Actinoptychus octonarius Ehrenberg (Bacillariophyta) isolated from Manzanillo, Colima, in the Mexican Pacific coast
}

\section{Morfología y capacidad antibacteriana potencial de Actinoptychus octonarius Ehrenberg (Bacillariophyta) aislado de Manzanillo, Colima, en la costa del Pacífico mexicano}

Zatarain-Palacios, R. ${ }^{1}$, Quijano-Scheggia, S. ${ }^{2}$, Gaytán-Hinojosa, M. A. ${ }^{1}$, Parra-Delgado, $H^{1}$, Salas-Marias, N. $^{2}$, Dagnino-Acosta, A. ${ }^{3}$, Ceballos-Magaña, S. G. ${ }^{4}$, Muñiz-Valencia, R. $^{1 *}$

${ }^{1}$ Facultad de Ciencias Químicas, Universidad de Colima, Carretera Colima-Coquimatlán km 9, 28400 Coquimatlán, Colima, México. ${ }^{2}$ Centro Universitario de Investigaciones Oceanológicas, Universidad de Colima, carretera Manzanillo-Barra de Navidad Km 20, Colima. México. ${ }^{3}$ CONACyT-Universidad de Colima, Avenida Universidad, 333, Colima, 28040 Colima, México. ${ }^{4}$ Facultad de Ciencias, Universidad de Colima, c/ Bernal Díaz del Castillo 340, 28045 Colima, Colima, México.

Cite this paper/Como citar este artículo: Zatarain-Palacios, R., Quijano-Scheggia, S., GaytánHinojosa, M. A., Parra-Delgado, H., Salas-Marias, N., Dagnino-Acosta, A., Ceballos-Magaña, S. G., Muñiz-Valencia, R. (2020). Morphology and potential antibacterial capability of Actinoptychus octonarius Ehrenberg (Bacillariophyta) isolated from Manzanillo, Colima, in the Mexican Pacific coast. Revista Bio Ciencias 7, e988. doi: https://doi.org/10.15741/revbio.07.e988

\section{A B S T R A C T}

Microalgae are present in all habitats, mainly in aquatic ones, both in marine and freshwater environments. Recently, these marine microorganisms gained attention because of their health benefits, especially when addressing the problem of antibiotic resistance. In this study, Actinoptychus octonarius Ehrenberg was identified by its ultrastructural details by Scanning Electron Microscopy (SEM). Additionally, the antibacterial properties of $A$. octonarius Ehrenberg were evaluated employing the method of disk diffusion against Staphylococcus aureus and Vibrio vulnificus bacteria. Four $A$. octonarius Ehrenberg extracts were obtained by the sequential multi-solvent extraction process using hexane, dichloromethane, methanol, and water.

Article Info/Información del artículo

Received/Recibido: June 03 ${ }^{\text {rd }} 2020$.

Accepted/Aceptado: October $12^{\text {th }} 2020$.

Available on line/Publicado: November $23^{\text {th }} 2020$.
RES U M E N

Las microalgas están presentes en todos los hábitats, mayormente acuáticos, tanto en ambientes marinos como dulceacuícolas. Recientemente, estos microorganismos marinos llamaron la atención debido al impacto de sus derivados en la salud, especialmente al abordar el problema de la resistencia a los antibióticos. En este estudio, se identificó y describió a Actinoptychus octonarius Ehrenberg por sus detalles ultraestructurales mediante microscopía electrónica de barrido (SEM). Además, se evaluaron las propiedades antibacterianas de ésta contra Staphylococcus aureus y Vibrio vulnificus empleando el método de difusión en disco. Con este fin, se obtuvieron cuatro extractos de la microalga por medio del proceso de extracción secuencial multidisolvente, usando primero hexano, luego diclorometano, posteriormente metanol y por último agua. Se observó el mayor efecto de la actividad antibacteriana contra $S$. aureus y $V$. vulnificus con el extracto metanólico. El extracto de hexano mostró actividad solo contra $S$. aureus. Ambos extractos mostraron un área de 
The best antibacterial activity was observed for the methanol extract, which had a significant effect against $S$. aureus and $V$. vulnificus. The area of inhibition of the extracts was higher to $1 \mathrm{~cm}^{2}$. Hexane extracts showed a limited antibacterial activity only against $S$. aureus and showing no significant effects against $V$. vulnificus. The aqueous and dichloromethane extracts did not present antibacterial activity. In summary, this study revealed, for the first time, morphological characteristics of A.octonarius Ehrenberg diatom through a SEM method. Furthermore, it was observed that molecules present in the methanolic extracts of $A$. octonarius Ehrenberg have antibacterial action against Gram-positive $S$. aureus and Gram-negative V. vulnificus, while the hexane extract showed effect only against $V$. vulnificus.

\section{KEY WORDS}

Actinoptychus octonarius; multi-solvent extraction; antimicrobial resistance.

\section{Introduction}

Infections caused by antibiotic-resistant bacteria have become a challenge for the health sector worldwide. The World Health Organization (WHO) suggested that it is required to invest in research and development of new antibiotics for the following resistant bacteria: Acinetobacter baumannii, Pseudomonas aeruginosa, Enterobacteriaceae, Enterococcus faecium, Staphylococcus aureus, Helicobacter pylori, Campylobacter spp., Salmonellae, and Neisseria gonorrhoeae (WHO, 2017). One of the possible solutions to control the infections caused by these bacteria could be through the isolation of antimicrobial compounds from natural products. For centuries, marine organisms including seaweeds have been used in traditional medicine due to their therapeutic potential for the treatment of a variety of diseases and also as nutritional elements and cosmetics. In this sense, a vast variety of marine compounds (e.g. carotenoids, phytosterols, vitamins, lipids, including omega-3 fatty acids and antioxidants) are employed in a broad spectrum of applications such as pharmaceuticals, cosmetics, human and animal nutrition (Desbois \& Smith, 2010; De Morais et al., 2015; De Jesus Raposo et al., 2015; Stonik \& Stonik, 2015). halo de inhibición mayor a $1 \mathrm{~cm}^{2}$. La actividad antibacteriana de los extractos acuosos y de diclorometano fue negativa. En este trabajo, se muestran por primera vez imágenes de SEM relevantes que muestran detalladamente características morfológicas de esta diatomea, por otra parte, se observó que los extractos metanólicos de $A$. octonarius Ehrenberg contienen moléculas con acción antibacteriana contra $S$. aureus (Grampositivo) y V. vulnificus (Gram-negativo).

\section{PALABRAS CLAVE}

Actinoptychus octonarius; extracción multidisolvente; resistencia antimicrobiana.

\section{Introducción}

Las infecciones causadas por bacterias resistentes a los antibióticos se han convertido en un desafío para el sector de la salud en todo el mundo. La Organización Mundial de la Salud (WHO) sugirió que es necesario invertir en investigación y desarrollo de nuevos antibióticos para las siguientes bacterias resistentes: Acinetobacter baumannii, Pseudomonas aeruginosa, Enterobacteriaceae, Enterococcus faecium, Staphylococcus aureus, Helicobacter pylori, Campylobacter spp., Salmonellaepp. y Neisseria gonorrhoeae (WHO, 2017). Una de las posibles soluciones para controlar las infecciones causadas por estas bacterias podría ser mediante el aislamiento de compuestos antimicrobianos de productos naturales. Durante siglos, los organismos marinos, incluidas las algas marinas, se han utilizado en la medicina tradicional debido a su potencial terapéutico para el tratamiento de una variedad de enfermedades y también como elementos nutricionales y cosméticos. En este sentido, una amplia variedad de compuestos marinos (por ejemplo, carotenoides, fitoesteroles, vitaminas, lípidos, incluidos los ácidos grasos omega-3 y antioxidantes) se emplean en un amplio espectro de aplicaciones como productos farmacéuticos, cosméticos, nutrición humana y animal (Desbois \& Smith, 2010; De Morais et al., 2015; De Jesus Raposo et al., 2015; Stonik \& Stonik, 2015).

Las diatomeas son organismos eucariotas que se encuentran en ambientes marinos, de agua dulce e incluso 
Diatoms are eukaryotic organisms that are found in marine, freshwater and even terrestrial environments. These photoautotrophic and unicellular organisms live in groups forming colonies of microalgae. They belong to the Bacillariophyceae class derived from the genus Bacillaria (Round, 1990). Diatoms play a crucial role in the fields of biology and environmental sciences.

They are an important part of the marine animal food chain since they generate most of the organic matter that serves for food. Additionally, they influence the global climate as they consume atmospheric carbon dioxide (Malve, 2016). Many diatoms studies have focused on the determination of active molecules with antibacterial, antifungal, antiprotozoal, anti-inflammatory and anticancer applications (Blunt et al., 2015, 2017; Mayer et al., 2017). However, the diatom strains spectrum is abundant, and the pharmaceutical utility of several of these species remains to be elucidated.

Biogeographic and ecological studies evidenced that there is great biodiversity in central diatoms of the genus Bacillariophyceae and Fragilariophyceae, which are found on the coast of the Mexican Pacific (LópezFuerte et al., 2006, 2015; Rivera-Vilarelle et al., 2013; Siqueiros-Beltrones et al., 2017; Woolrich-Arrioja et al., 2019). It is suggested that diatoms are a vast source of new molecules with antibacterial properties, raising a possible utility for the treatment of resistant bacterial strains not affected by conventional drugs. Furthermore, it is important to identify the location of diatom species in aquatic areas. In this sense, $A$. octonarius is a poorly studied diatom and is not commonly found in other regions; therefore it is relevant to study its antibiotic action for a possible repertoire expansion of bioactive molecules with this property. Nevertheless, there are several types of central diatoms belonging to a different taxon which hold characteristics that differ slightly. Therefore, their differentiation is a difficult task. However, scanning electron microscope (SEM) is a high-resolution optical tool allowing the identification of unique morphological features that otherwise would be impossible to observe.

This study aimed to isolate and identify (by SEM) diatom A. octonarius Enherberg which is found in the region of Lagoon Juluapan in the central zone of the Mexican Tropical Pacific Ocean. A. octonarius Enherberg was first roughly described by Ehrenberg Kützing in 1843 ambientes terrestres. Estos organismos fotoautótrofos y unicelulares viven en grupos formando colonias de microalgas. Ellas pertenecen a la clase Bacillariophyceae derivada del género Bacillaria (Round, 1990). Las diatomeas juegan un papel crucial en los campos de la biología y las ciencias ambientales.

Son parte importante de la cadena alimentaria de los animales marinos, ya que generan la mayor parte de la materia orgánica que sirve como alimento. Además, influyen en el clima global debido a que consumen dióxido de carbono atmosférico (Malve, 2016). Muchos estudios de diatomeas se han centrado en la determinación de moléculas activas con aplicaciones antibacterianas, antifúngicas, antiprotozoarias, antiinflamatorias y anticancerígenas (Blunt et al., 2015, 2017; Mayer et al., 2017). Sin embargo, el espectro de cepas de diatomeas es abundante y la utilidad farmacéutica de varias de estas especies aún no se ha elucidado.

Estudios biogeográficos y ecológicos evidenciaron que existe una gran biodiversidad en diatomeas centrales del género Bacillariophyceae y Fragilariophyceae, que se encuentran en la costa del Pacífico mexicano (López-Fuerte et al., 2006, 2015; Rivera-Vilarelle et al., 2013; SiqueirosBeltrones et al., 2017; Woolrich-Arrioja et al., 2019). Es sugerido que las diatomeas son una gran fuente de nuevas moléculas con propiedades antibacterianas, lo que plantea una posible utilidad para el tratamiento de cepas bacterianas resistentes no afectadas por fármacos convencionales. Además, es importante identificar la ubicación de las especies de diatomeas en áreas acuáticas. En este sentido, $A$. octonarius es una diatomea poco estudiada y no se encuentra comúnmente en otras regiones; por tanto, es relevante estudiar su acción antibiótica para una posible expansión del repertorio de moléculas bioactivas con esta propiedad. Sin embargo, existen varios tipos de diatomeas centrales pertenecientes a diferentes taxones que tienen características que difieren ligeramente. Por tanto, su diferenciación es una tarea difícil. Sin embargo, el microscopio electrónico de barrido (SEM) es una herramienta óptica de alta resolución que permite la identificación de características morfológicas únicas que de otro modo serían imposibles de observar.

Este estudio tuvo como objetivo aislar e identificar (por SEM) a la diatomea $A$. octonarius Enherberg que se encuentra en la región de la Laguna Juluapan en la zona central del Océano Pacífico Tropical Mexicano. A. octonarius Enherberg fue descrito de manera aproximada por Ehrenberg Kützing en 1843 (Lavigne \& Guiry, 2018a). 
Lavigne \& Guiry (2018a). Also, the antibacterial activity of the diatom was evaluated by sequential multi-solvent extraction and disk diffusion assay.

\section{Material and Methods}

Sampling area, sample collection and $A$. octonarius Ehrenberg isolation

Water samples were collected monthly during 2017 on the Juluapan lagoon, which is located on the central zone of the Mexican Pacific Ocean (19 ${ }^{\circ} 06^{\prime} 59.1^{\prime \prime}$ $\mathrm{N}$ and $104^{\circ} 24^{\prime} 20.7^{\prime \prime} \mathrm{W}$ ). This lagoon drains into the Santiago Bay, which is connected to the west side of the Manzanillo Bay. The lagoon and the Santiago bay are both semicircular and open to the sea (Figure 1). The samples $(40 \mathrm{~L})$ were collected randomly on the surface of the water and transported to the laboratory in capped transparent plastic bottles at ambient temperature.

For the A. octonarius Ehrenberg isolation, on the same day of the sampling, an inspection of a portion of the water sample was made by means of an inverted optical
Además, la actividad antibacteriana de la diatomea se evaluó mediante extracción secuencial con múltiples disolventes y ensayo de difusión en disco.

\section{Material y Métodos}

Área de muestreo, toma de muestra y aislamiento de $A$. octonarius Ehrenberg

Las muestras de agua se colectaron mensualmente, durante 2017, en la Laguna de Juluapan, la cual se localiza en la zona central del Océano Pacífico Mexicano (1906'59.1" $\mathrm{N}$ and $104^{\circ} 24^{\prime} 20.7^{\prime \prime} \mathrm{W}$ ). Esta laguna desemboca en la Bahía de Santiago, que está conectada con el lado oeste de la había de Manzanillo. La laguna y la Bahía de Santiago tienen forma semicircular y están abiertas al mar (Figure 1). Las muestras $(40 \mathrm{~L})$ se recogieron aleatoriamente en la superficie del agua y se transportaron al laboratorio en botellas de plástico transparentes tapadas a temperatura ambiente.

Para el aislamiento de $A$. octonarius Ehrenberg, el mismo día del muestreo, se realizó una inspección de una porción de la muestra de agua mediante un microscopio óptico invertido

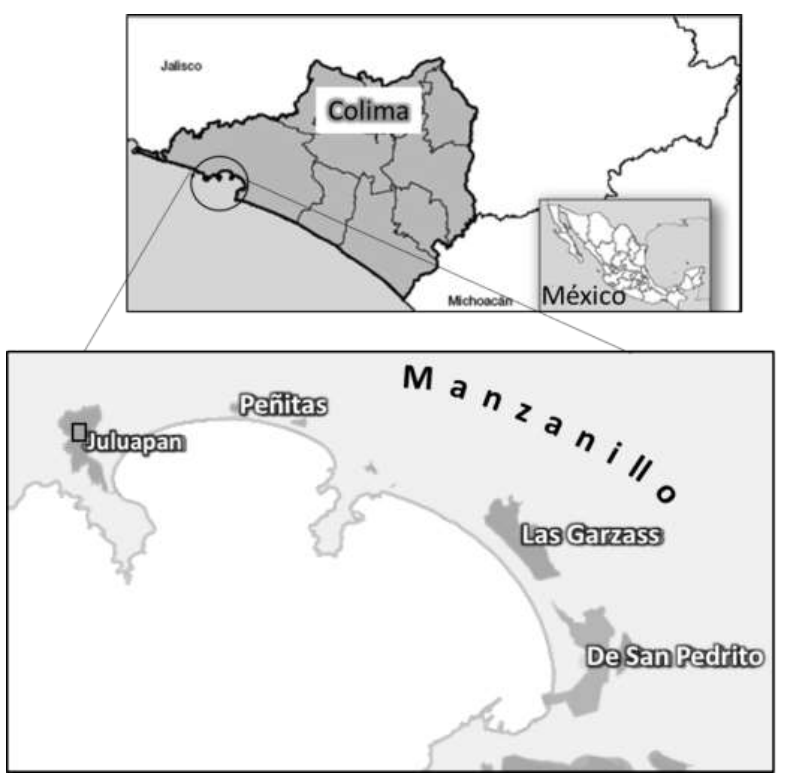

Figure 1. Location of the Juluapan lagoon, Colima, México. Source INEGI (Mexico). Coordinates: 1906'59.1' N and 104'24'20.7' W.

Figura 1. Ubicación de la Laguna de Juluapan, Colima, México. Fuente INEGI (México). Coordenadas: $19^{\circ} 06^{\prime} 59.1^{\prime \prime}$ N y 104²4'20.7' W. 
microscope (Motic AE31; Jed Pella, Redding, CA, USA). Once $A$. octonarius Ehrenb was identified taking into account its morphological characteristics (smooth external valve and presence of pseudonodule), a glass Pasteur pipette was used to separate diatoms of the same species.

\section{A. octonarius Ehrenberg culture and growth.}

For its culture, a modified L1 medium described by Guillard \& Hargraves (1993) was used, this method involves the addition of vitamin B12 (cyanocobalamin), Biotin and Thiamine- $\mathrm{HCl}$. The medium was prepared using cold seawater, which was sterilized, filtered and autoclaved at $121{ }^{\circ} \mathrm{C}$ for 20 minutes. All cultures were maintained at $21^{\circ} \mathrm{C}$ in a $12: 12$ hours light/dark cycle. Illumination was provided by fluorescent tubes (Phillips F96T12/TL865/EW, $60 \mathrm{~W}$, Mexico) with a photon irradiance of $90 \mu \mathrm{mol}$ photons $/ \mathrm{m}^{2} \mathrm{~s}$.

The diatom culture was initiated with 10 cells into a tissue culture plate with $0.2 \mathrm{~mL}$ of medium. After one week, A. octonarius Ehrenberg was cultivated in 20 $\mathrm{mL}$ of culture medium. When the diatoms' cell density reached 10,000 cells $/ \mathrm{mL}$, the volume of the medium was increased to $50 \mathrm{~mL}$. When those $50 \mathrm{~mL}$ reached a density of 10,000 cells $/ \mathrm{mL}$, the volume of the medium was increased to $1,000 \mathrm{~mL}$. The culture was gently shaken by hand two times daily for $1 \mathrm{~min}$ to allow gas exchange, which promotes an increase of biomass. This procedure was performed in duplicate. Also, the culture was maintained reseeding $50 \mathrm{~mL}$ of inoculum in 1,000 $\mathrm{mL}$ of culture medium.

\section{Growth curve measurement}

The microalga growth curve started with an initial density of $10,000 \mathrm{cell} / \mathrm{mL}$. The total volume of the media was $250 \mathrm{~mL}$. The cells were counted using a SedgwickRafter chamber (Graticules Ltd., UK) which consisted of a slide with a rectangular frame of $50 \times 20 \mathrm{~mm}$ and $1 \mathrm{~mm}$ deep. The exponential growth was quantified and performed in quadruplicate every 24 hours.

\section{Cell harvest and lyophilization}

The diatoms harvest was performed at the time of the maximum exponential growth rate, which occurred on the $13^{\text {th }}$ day. For harvesting the diatom cells, a $50 \mathrm{~mL}$ conical tube was filled with diatoms culture and centrifuged at $450 \times \mathrm{g}$ for $10 \mathrm{~min}$. The procedure
(Motic AE31; Jed Pella, Redding, CA, EE. UU.). Una vez identificado $A$. octonarius Ehrenb teniendo en cuenta sus características morfológicas (válvula externa lisa y presencia de pseudonódulus), se utilizó una pipeta Pasteur de vidrio para separar diatomeas de la misma especie.

\section{Cultivo y crecimiento de $A$. octonarius Ehrenberg.}

Para su cultivo, se usó el medio de cultivo L1 modificado descrito por Guillard \& Hargraves (1993), este método implica la adición de vitamina B12 (cianocobalmina), Biotina y tiamina- $\mathrm{HCl}$. El medio se preparó utilizando agua de mar fría, que se filtró y esterilizó en autoclave a $121{ }^{\circ} \mathrm{C}$ durante 20 minutos. Todos los cultivos se mantuvieron a 21 ${ }^{\circ} \mathrm{C}$ en un ciclo de luz/oscuridad de 12:12 horas. La iluminación fue proporcionada por tubos fluorescentes (Phillips F96T12 / TL865 / EW, 60 W, México) con una irradiación de fotones de $90 \mu \mathrm{mol}$ fotones $/ \mathrm{m}^{2} \mathrm{~s}$.

El cultivo de diatomeas se inició con 10 células en una placa de cultivo de tejidos con $0.2 \mathrm{~mL}$ de medio. Después de una semana, se cultivó $A$. octonarius Ehrenberg en $20 \mathrm{~mL}$ de medio de cultivo. Cuando la densidad celular de las diatomeas alcanzó las 10,000 células $/ \mathrm{mL}$, el volumen del medio se incrementó a 50 $\mathrm{mL}$. Cuando esos $50 \mathrm{~mL}$ alcanzaron una densidad de 10,000 células $/ \mathrm{mL}$, el volumen del medio se incrementó a 1,000 mL. El cultivo se agitó suavemente a mano dos veces al día durante 1 minuto para permitir el intercambio de gases, lo que promueve un aumento de la biomasa. Este procedimiento se realizó por duplicado. Además, el cultivo se mantuvo resembrando $50 \mathrm{~mL}$ de inóculo por cada $1000 \mathrm{~mL}$ de medio de cultivo.

\section{Medición de la curva de crecimiento}

La curva de crecimiento de microalgas comenzó con una densidad inicial de 10,000 células/mL. El volumen total del medio fue $250 \mathrm{~mL}$. Las células se contaron usando una cámara Sedgwick-Rafter (Graticules Ltd., Reino Unido) que consistía en un portaobjetos con un marco rectangular de $50 \mathrm{x}$ $20 \mathrm{~mm}$ y $1 \mathrm{~mm}$ de profundidad. El crecimiento exponencial se cuantificó y se realizó por cuadriplicado cada 24 horas.

\section{Recolección y liofilización de células}

La cosecha de diatomeas se realizó en el momento de la máxima tasa de crecimiento exponencial, que ocurrió el día 13. Para recolectar las células de diatomeas, un tubo cónico de $50 \mathrm{~mL}$ se llenó con cultivo de diatomeas y se centrifugó a $450 \mathrm{xg}$ durante $10 \mathrm{~min}$. El procedimiento se repitió utilizando el mismo tubo cónico hasta que se 
was repeated using the same conical tube until all the diatoms culture was centrifuged. The harvest of diatoms biomass culture resulted in a pellet that was lyophilized using the Freeze Dry System Freezone 6 (Labconco Corporation, Kansas City, MI, USA). Finally, the lyophilized diatoms were weighed and stored at $-78^{\circ} \mathrm{C}$ until its subsequent use.

\section{Leaching of microalgae by solvent extraction}

HPLC grade hexane, dichloromethane and methanol $(\mathrm{MeOH})$ and ultrapure water (Milli-Q type) were used for the extraction procedure (Figure 2).

Initially, $1 \mathrm{~g}$ of dried microalgae was homogenized in a porcelain mortar with pestle and transferred to a glass tube containing $10 \mathrm{~mL}$ of solvent, followed by sonication using three periods of $20 \mathrm{~min}$ with a 5 min resting interval. The samples were centrifuged (Labogene centrifugó todo el cultivo de diatomeas. De la cosecha de biomasa de diatomeas se obtuvo un pellet el cual se liofilizó con el sistema Freeze Dry System Freezone 6 (Labconco Corporation, Kansas City, MI, EE. UU.). Finalmente, las diatomeas liofilizadas se pesaron y almacenaron a $-78{ }^{\circ} \mathrm{C}$ hasta su posterior uso.

\section{Lixiviación de microalgas por extracción con disolventes}

Para el procedimiento de extracción se utilizaron hexano, diclorometano y metanol $(\mathrm{MeOH})$ de grado HPLC y agua ultrapura (tipo Milli-Q) (Figura 2).

Inicialmente, $1 \mathrm{~g}$ de microalgas secas fue homogeneizada en un mortero de porcelana con pistilo y transferida a un tubo de vidrio que contenía $10 \mathrm{~mL}$ de disolvente, seguido de sonicación mediante tres períodos de 20 min con un intervalo de reposo de $5 \mathrm{~min}$. Las muestras fueron centrifugadas (Labogene 1580R,

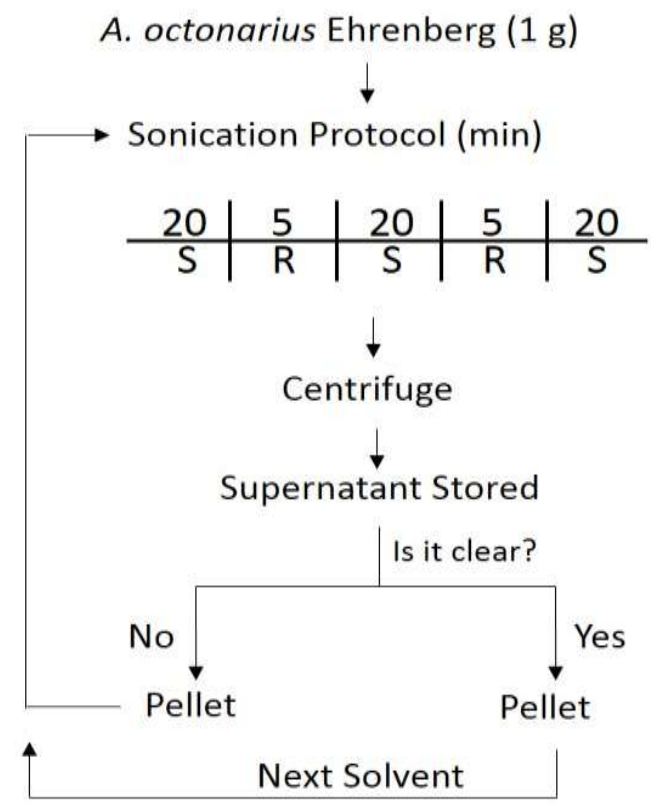

Figure 2. Steps followed for the sequential multisolvent extraction from $A$. octonarius Ehrenberg. The solvents employed were chosen considering the polarity (from the lowest to highest polarity): hexane $<$ dichloromethane $<$ methanol $<$ water. Sonication time (S); Resting time (R).

Figura 2. Pasos seguidos para la extracción secuencial multidisolvente de $A$. octonarius Ehrenberg. Los disolventes empleados se eligieron teniendo en cuenta la polaridad (de la polaridad más baja a la más alta): hexano < diclorometano < metanol < agua. Tiempo de sonicación (S); Tiempo de descanso (R). 
1580R, LaboGene, Lynge, Denmark) for 10 min (1,000 $\mathrm{xg}, 4{ }^{\circ} \mathrm{C}$ ) and the supernatant was quickly visually inspected and then transferred to a clean and sterile glass tube for storage at $4{ }^{\circ} \mathrm{C}$. If the supernatant was still opaque then the pellet was resuspended in fresh solvent and the sonication-centrifugation process was repeated, otherwise, if the supernatant was clear, the pellet was resuspended in the next solvent following the increasing order of polarity. Each supernatant obtained with the same solvent was combined and concentrated in a Büchi Rotavapor R-114 (Büchi Labortechnik GmbH, Essen, Germany). This sequential multi-solvent extraction process was arranged according to the polarity of solvents, starting with a non-polar solvent (hexane), then dichloromethane, subsequently methanol, and finishing with the most polar solvent of the group (water). This sequential multi-solvent extraction process permitted the extraction according to the polarity of molecules, from non-polar in hexane to polar in water (Garcia-Argaez et al., 2000; Zubair et al., 2016).

\section{Morphological analysis with Scanning Electronic Microscope (SEM)}

The organic material was removed from the samples taking $50 \mathrm{~mL}$ diatoms culture media and centrifuging at $450 \mathrm{xg}$ for $10 \mathrm{~min}$, the pellet was then washed out first with $10 \mathrm{~mL}$ of distilled water (centrifuge at $450 \mathrm{xg}$ for $10 \mathrm{~min}$ ), then adding $10 \mathrm{~mL}$ of $\mathrm{H}_{2} \mathrm{SO}_{4}$ (30 $\%$ ) and $10 \mathrm{~mL}$ of saturated $\mathrm{KMnO}_{4}$ were added, followed by $24 \mathrm{~h}$ incubation. The next day, the sample was bleached by adding $10 \mathrm{~mL}$ of saturated $\mathrm{H}_{2} \mathrm{C}_{2} \mathrm{O}_{4}$ (oxalic acid), and washed with distilled water as described by Lundholm et al. (2002). Finally, a drop of the sample was mounted on a polycarbonate filter, dried and stored until use. For micrography, the filter is attached to stubs with colloidal silver, the sample is sputter-coated with gold and observed at 20-30 kV under a scanning electronic microscope (JEOL, USA) in high vacuum and secondary electron emission mode.

\section{Bacterial cultures}

S. aureus strain was cultivated in mannitol salt agar. Then, one colony was cultivated in a brain heart infusion broth. The confirmation of $S$. aureus strain was done by performing a coagulase and a catalase test (Vandepitte et al., 2003). For the disk diffusion test, one colony was incubated in a $12 \mathrm{~mL}$ brain heart infusion broth. This bacteria culture was used to prepare bacterial suspension
LaboGene, Lynge, Denmark) por $10 \min \left(1,000 \mathrm{xg}, 4^{\circ} \mathrm{C}\right) \mathrm{y}$ rápidamente, el sobrenadante se inspeccionó visualmente y después se transfirió a un tubo de vidrio limpio y estéril para su almacenamiento a $4{ }^{\circ} \mathrm{C}$. Si el sobrenadante todavía era opaco, el pellet se resuspendía en más disolvente y se repetía el proceso de sonicación-centrifugación; de lo contrario, si el sobrenadante era transparente, el pellet se resuspendía en el siguiente disolvente, siguiendo el orden creciente de polaridad. Cada sobrenadante obtenido con el mismo disolvente se combinó y se concentró en un Büchi Rotavapor R-114 (Büchi Labortechnik $\mathrm{GmbH}$, Essen, Alemania). Este proceso de extracción secuencial multidisolvente se organizó según la polaridad de los disolventes, inició con el disolvente apolar (hexano), luego diclorometano, posteriormente metanol y terminó con el disolvente más polar del grupo (agua). Este proceso secuencial de extracción multidisolvente permitió la extracción según la polaridad de las moléculas, desde no polares en hexano hasta polares en agua. (Garcia-Argaez et al., 2000; Zubair et al., 2016).

\section{Análisis morfológico con Microscopio Electrónico de Barrido (SEM)}

El material orgánico se removió de las muestras tomando $50 \mathrm{~mL}$ de medio de cultivo de diatomeas y centrifugando a $450 \mathrm{xg}$ durante $10 \mathrm{~min}$, luego se lavó el pellet primero con $10 \mathrm{~mL}$ de agua destilada (centrifugar a $450 \mathrm{xg}$ durante $10 \mathrm{~min}$ ), luego se adicionó $10 \mathrm{~mL}$ de $\mathrm{H}_{2} \mathrm{SO}_{4}\left(30 \%\right.$ ) y $10 \mathrm{~mL}$ de $\mathrm{KMnO}_{4}$ saturado, seguido de 24 $\mathrm{h}$ de incubación. Al día siguiente, se blanqueó la muestra añadiendo $10 \mathrm{~mL}$ de $\mathrm{H}_{2} \mathrm{C}_{2} \mathrm{O}_{4}$ saturado (ácido oxálico) y se enjuagó con agua destilada como describen Lundholm et al. (2002). Finalmente, se montó una gota de la muestra en un filtro de policarbonato, se secó y se almacenó hasta su uso. Para la micrografía, el filtro se fijó a colillas de plata coloidal, la muestra se recubre por pulverización catódica con oro y se observa a $20-30 \mathrm{kV}$ bajo un microscopio electrónico de barrido (JEOL, EE. UU.) en modo de alto vacío y emisión de electrones secundarios.

\section{Cultivo de bacterias}

La cepa de $S$. aureus se cultivó en agar con sal de manitol. Luego, una colonia se cultivó en medio de infusión de cerebro-corazón. La confirmación de la cepa de $S$. aureus se realizó mediante la prueba de coagulasa y catalasa (Vandepitte et al., 2003). Para la prueba de difusión en disco, una colonia se incubó en $12 \mathrm{~mL}$ del medio de infusión cerebro-corazón. Este cultivo de bacterias se utilizó para preparar una suspensión bacteriana que contenía aproximadamente $1 \times 10^{8}$ unidades formadoras de colonias 
containing approximately $1 \times 10^{8}$ colony forming units $(\mathrm{CFU}) / \mathrm{mL}$, equivalent to $0.5 \mathrm{McF}$ arland standard solution. The McFarland standard solution was prepared following the procedure described at the CLSI (2006). All cultures were incubated at $37^{\circ} \mathrm{C}$ for $24 \mathrm{~h}$.

V. vulnificus strain was first cultivated in tryptic soy agar (TSA) with $1 \% \mathrm{NaCl}$. Then, one colony was cultivated in peptone water at $\mathrm{pH}=9$ and $1 \% \mathrm{NaCl}$ and incubated for 8 hours at $37{ }^{\circ} \mathrm{C}$ to stimulate the growth of the strain (Hsu et al., 1998). Afterward, an inoculation loop was immersed into the liquid culture and streaked in thiosulfate citrate bile salts sucrose (TCBS) (incubation at $37{ }^{\circ} \mathrm{C}$ for $24 \mathrm{~h}$ ) as a selective medium for $\mathrm{V}$. vulnificus. In the TCBS medium, the colonies grow with a bluishgreen color (Lotz et al., 1983). Thereafter, a single bluish-green colony was then streaked in TSA. Since V. vulnificus is a moderately halophilic bacterium, it proliferates in a saturated salt solution. Therefore, the growth of $V$. vulnificus was confirmed by its proliferation in a medium with a $\mathrm{NaCl}$ concentration ranging from 3-6 $\%$ mass (Kaysner et al., 2004). For the disk diffusion test, a single colony was used to prepare bacterial suspension containing approximately $1 \times 10^{8} \mathrm{CFU} / \mathrm{mL}$.

\section{Disk diffusion test with $A$. octonarius extracts}

For this purpose, the methodology proposed by Desbois \& Smith (2015) was carried out. A culture of the bacteria ( $S$. aureus and V. vulnificus), added with $10 \mathrm{~mL}$ of a solution with $1 \times 10^{8} \mathrm{CFU} / \mathrm{mL}$, was prepared in its proper liquid medium and grown for $24 \mathrm{~h}$.

The bacteria were taken with a sterile cotton wool swab and seeded onto Petri dishes containing Mueller-Hinton agar. At the same time, $1 \mathrm{mg}$ of extracts were dissolved in its original solvent (hexane, dichloromethane, methanol or water) and applied in steps of $20 \mu \mathrm{L}$ onto the center of the sterile $6 \mathrm{~mm}$ antibiotic assay paper disk (AA; GE Healthcare, Whatman). A negative control disk was impregnated with an equivalent volume of the proper solvent. Both disks (negative control and extract) were mounted onto Petri dishes prepared with bacteria on the Mueller-Hinton agar (Desbois \& Smith, 2015). The plates that held the impregnated paper disk with extract and negative control disk were incubated at $37^{\circ} \mathrm{C}$ for $24 \mathrm{~h}$.

The area of growth inhibition $\left(A_{G I}\right)$ was calculated using the following equation $A_{G I}=A_{C Z}-A_{P D}$, where $A_{C Z}$ is the area
(CFU)/mL, equivalente a la solución estándar $0.5 \mathrm{McF}$ arland. La solución estándar $0.5 \mathrm{McF}$ arland se preparó siguiendo el procedimiento descrito en el CLSI (2006). Todos los cultivos se incubaron a $37^{\circ} \mathrm{C}$ durante $24 \mathrm{~h}$.

La cepa de $V$. vulnificus se cultivó primero en agar tripticaseína de soja (TSA) con $\mathrm{NaCl}$ al $1 \%$. Luego, una colonia se cultivó en agua de peptona a $\mathrm{pH}=9$ y $\mathrm{NaCl}$ al $1 \%$ y se incubó durante 8 horas a $37{ }^{\circ} \mathrm{C}$ para estimular el crecimiento de la cepa (Hsu et al., 1998). Posteriormente, un asa de inoculación se sumergió en el cultivo líquido y se esparció en el agar tiosulfato, citrato, sales biliares, sacarosa (TCBS) (incubación a $37^{\circ} \mathrm{C}$ por 24 horas) como medio selectivo para V. vulnificus. En el medio TCBS, las colonias crecen con un color verde azulado (Lotz et al., 1983). A partir de entonces, una sola colonia verde-azul se estrió en TSA. Dado que $V$. vulnificus es una bacteria moderadamente halófila, prolifera en solución salina saturada. Por lo tanto, el crecimiento de $\checkmark$. vulnificus fue confirmado por su proliferación en un medio con una concentración de $\mathrm{NaCl}$ que oscila entre el 3 y el $6 \%$ en masa (Kaysner et al., 2004). Para la prueba de difusión en disco, se usó una sola colonia para preparar una suspensión bacteriana que contenía aproximadamente $1 \times 10^{8} \mathrm{CFU} / \mathrm{mL}$.

\section{Ensayo de difusión en disco con extractos de A. octonarius}

Para este propósito, se llevó a cabo la metodología propuesta por Desbois \& Smith (2015). Se preparó un cultivo de la bacteria ( $S$. aureus y $V$. vulnificus), adicionada con $10 \mathrm{~mL}$ de una solución con $1 \times 10^{8} \mathrm{CFU} / \mathrm{mL}$, en su medio líquido adecuado y se dejó crecer por 24 h.

Las bacterias se tomaron con un hisopo de algodón estéril y se estriaron en placas de Petri que contenían agar MuellerHinton. Al mismo tiempo, se disolvió $1 \mathrm{mg}$ de extractos en su disolvente original (hexano, diclorometano, metanol o agua) y se impregnó en pasos de $20 \mu \mathrm{L}$ sobre el centro del disco de papel de ensayo de antibiótico estéril de $6 \mathrm{~mm}$ (AA; GE Healthcare, Whatman). Como control negativo, se impregnó un disco con un volumen equivalente del disolvente apropiado. Ambos discos (control negativo y extracto) se montaron en placas de Petri preparadas con bacterias en el agar Mueller-Hinton (Desbois \& Smith 2015). Las placas que contenían el disco de papel impregnado con extracto y el disco de control negativo se incubaron a $37^{\circ} \mathrm{C}$ durante $24 \mathrm{~h}$.

El área de inhibición del crecimiento $\left(A_{G I}\right)$ se calculó usando la siguiente ecuación $A_{G I}=A_{C Z}-A_{P D}$, donde $A_{C Z}$ es el área de la zona clara y $A_{P D}$ es el área del disco de papel. Las $A_{C Z} y$ 
of the cleared zone and $A_{P D}$ is the area of the paper disk. The $A_{C Z}$ and $A_{P D}$ were calculated using the equation $A=\pi r^{2}$ where $r$ is the circle radius. For $A_{c z}$, the circle radius was considered as:

$$
r=\frac{\left(d_{x}+d_{y}\right)}{4}
$$

Where $d x$ is the horizontal plane diameter and $d_{y}$ is the vertical plane diameter of the clear zone including the paper disk diameter, respectively. For $A_{P D}$ the circular radius was considered as:

$$
r=\frac{d}{2}
$$

Estimation of areas was carried out in triplicate and for each test a new fresh extract was assessed.

\section{Results}

\section{Morphological identification of A. octonarius} Ehrenberg

The identification of $A$. octonarius Ehrenberg based on their morphological features was accomplished through SEM technique. The presented SEM images show a high-resolution view of the diatom morphology (Figure 3). On the surface of the diatom is observed a smooth external valve, and close to the cell edge is also observed a characteristic hole of this diatom referred as pseudonodule (Figure 3a). The internal valve structure is observed covered by a high density of pores (Figure $3 b)$ and is deprived of sections as it is usually seen in Actinoptichus species found on the coast of Oaxaca, Mexico (Woolrich-Arrioja et al., 2019). The annulus is the central zone with a group of pores rounded by a hyaline area. This area separates the central pores from the rest of the pores that cover the inner valve (Figure $3 b-c$ ).

The pores seen on the internal valve are radial, parallelly distributed and organized in series of rows traveling from the hyaline central area to the edges.

The labiate processes were present in the middle of the mantle (Figure 3d). Their structure was cylindrical, where one end was settled on the valve and the other end joined to form a manual fan slot. In other words, the ends of the labiate processes bent towards the valve shelf creating a smile effect. The studied diatoms present from 10 to 26 labiate processes are always organized symmetrically in the mantle. This labiate
$A_{P D}$ fueron calculados con la ecuación $A=\pi r^{2}$ donde $r$ es el radio del círculo. Para $\mathrm{A}_{\mathrm{CZ}}$, el radio del círculo se consideró como:

$$
r=\frac{\left(d_{x}+d_{y}\right)}{4}
$$

Donde $d x$ es el diámetro del plano horizontal y $d y$ es el diámetro del plano vertical de la zona despejada, incluido el diámetro del disco de papel, respectivamente. Para $A_{P D}$ el radio circular se consideró como:

$$
r=\frac{d}{2}
$$

La estimación de áreas se realizó por triplicado y para cada prueba se evaluó un nuevo extracto fresco.

\section{Resultados}

\section{Identificación morfológica de $A$. octonarius Ehrenberg}

La identificación de $A$. octonarius Ehrenberg con base a sus características morfológicas se logró mediante la técnica SEM. Las presentes imágenes SEM muestran una vista de alta resolución de la morfología de las diatomeas (Figure 3). En la superficie de la diatomea se observa la valva externa lisa, y cerca del borde también se observa el pseudonodulus, un orificio característico de esta diatomea (Figure 3a). La estructura interna de la valva se observa cubierta por una alta densidad de poros (Figure 3b) y está desprovista de secciones como suele verse en las especies de Actinoptichus que se encuentran en la costa de Oaxaca, México (Woolrich-Arrioja et al., 2019). El annulus es la zona central de la valva, tiene un grupo de poros redondeados por un área hialina. Esta zona separa los poros centrales del resto de poros que cubren la valva interior (Figure 3b-c).

Los poros que se ven en la valva interna están distribuidos de forma radial, distribuidos paralelamente y organizados en series de filas que se desplazan desde el área central hialina hasta los bordes.

Los procesos labiados estaban presentes en el medio del manto (Figure 3d). Su estructura es cilíndrica, de un extremo se une la valva y del otro extremo se cierra para formar una figura como la de una ranura de ventilador manual. En otras palabras, los extremos de los procesos labiados se doblan hacia el estante de la valva creando un efecto de 

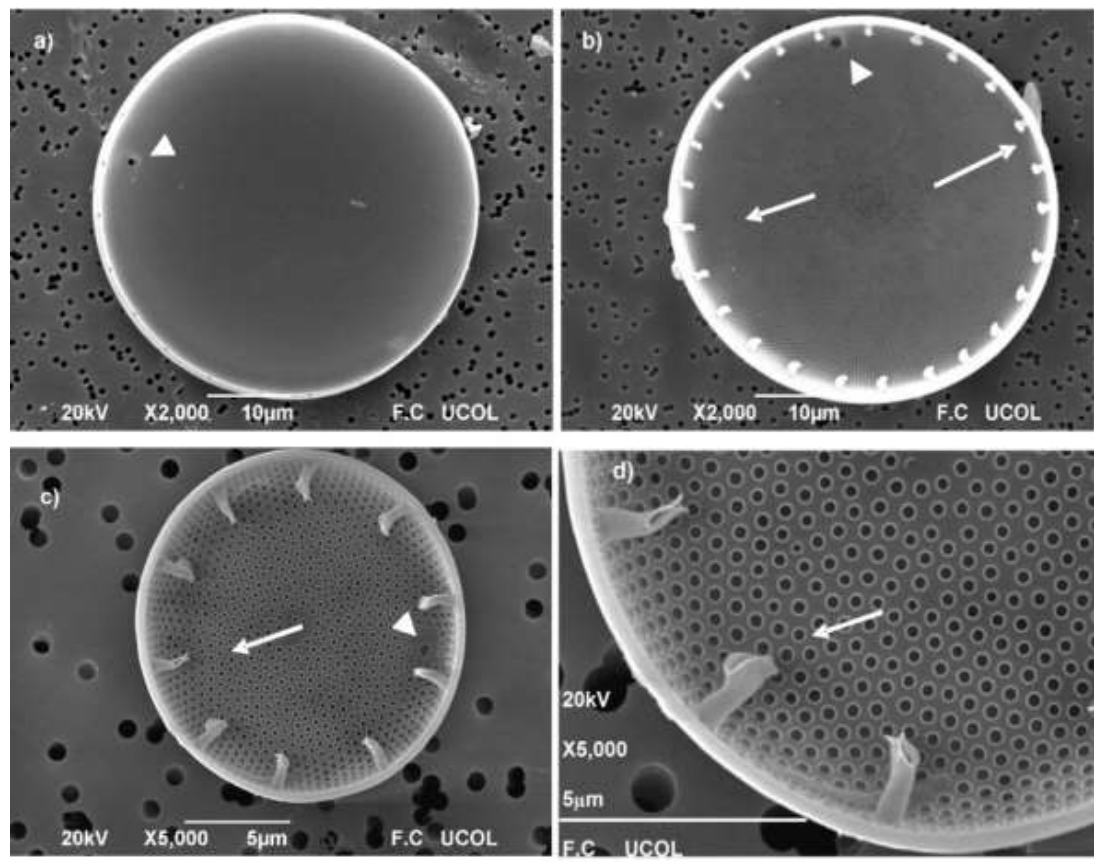

Figure 3. Scanning Electron Micrographs of $A$. octonarius Ehrenberg. a) valve external and pseudonodule external view (indicated by an arrow); b) valve internal view and the inserted labiate processes at the valve margin with the mantle (indicated by an arrow); c) pseudonodule greater amplification (indicated by arrowhead); and d) observation of the labiate processes ends (indicated by an arrow).

Figura 3. Micrografías electrónicas de barrido de $A$. octonarius Ehrenberg. a) vista externa de la válvula y pseudonodulus externa (indicada por una flecha); b) vista interna de la válvula y los procesos labiados insertados en el margen de la válvula con el manto (indicado por una flecha); c) Pseudonodulus mayor amplificación (indicado por punta de flecha); y d) vista de los procesos labiados finales (indicado por una flecha).

process variation in diatoms normally occurs due to the silica is deposited in varying combinations to build their siliceous walls depending on a multitude of events and processes.

The pseudonodule is always located near the fold of the mantle and is considered a representative characteristic of $A$. octonarius Ehrenberg. (Figure $3 a-c)$. The pseudonodule is a non-covered circular cavity communicating to the exterior of the cell. The pseudonodule is surrounded by a thickened hyaline area (Ross \& Sims, 1972).

\section{Diatom growth curve}

The optimal day of harvesting with the largest number of young cells required for further obtention of extracts was calculated by means its growth sonrisa. Las diatomeas estudiadas presentan de 10 a 26 procesos labiados siempre organizados simétricamente en el manto. Esta variación de los procesos labiados en las diatomeas ocurre normalmente debido a que la sílice que se deposita en diversas combinaciones para construir sus paredes silíceas dependiendo de una multitud de eventos y procesos.

El pseudonodulus siempre se encuentra cerca del pliegue del manto y se considera una característica representativa de $A$. octonarius Ehrenberg. (Figura 3a-c). El pseudonodulus es una cavidad circular no cubierta que se comunica con el exterior de la célula. El pseudonodulus está rodeado por un área hialina engrosada (Ross \& Sims, 1972).

\section{Curva de crecimiento de diatomeas}

El día óptimo de cosecha con el mayor número de células jóvenes requeridas para la obtención adicional de extractos se calculó mediante su curva de crecimiento. 


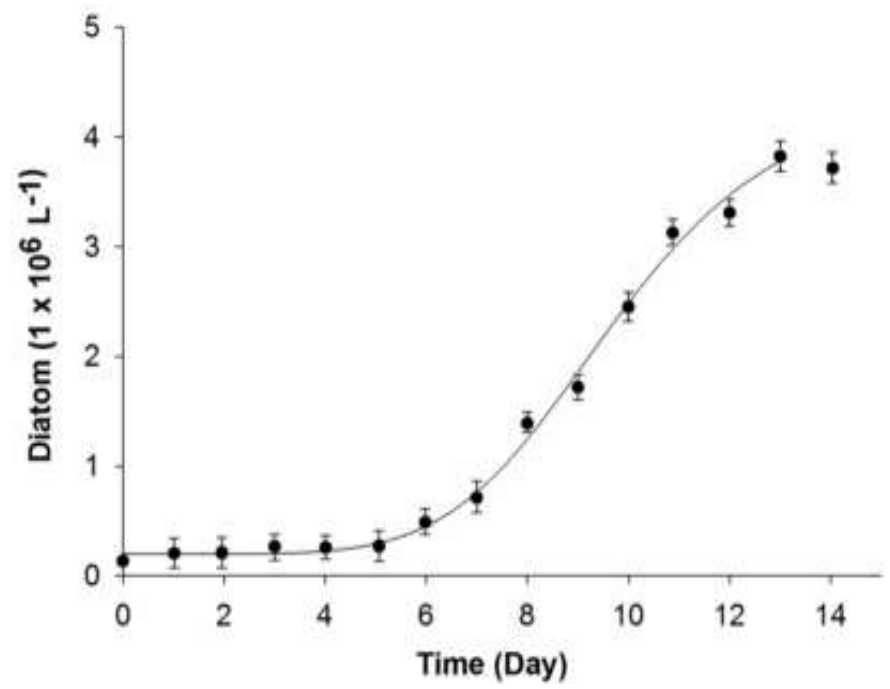

Figure 4. Growth curve of $A$. octonarius Ehrenberg cultured at temperature $21 \pm 2{ }^{\circ} \mathrm{C}$. Adjusted values with the equation Sigmoidal, Hill, 4 Parameter $(n=3)$.

Figura 4. Curva de crecimiento de $A$. octonarius Ehrenberg. Cultivado a temperatura $21 \pm 2^{\circ} \mathrm{C}$. Valores ajustados con la ecuación Sigmoidal, Hill, de 4 Parámetros $(n=3)$.

curve. According to our results shown in Figure 4, the maximum density of cells was observed at around the $13^{\text {th }}$ day of culture.

\section{Antibacterial activity of crude extracts}

The antibacterial potential of each solvent was separately evaluated against the pathogenic bacteria Gram-positive, S. aureus (Figure 5) and Gram-negative bacteria, V. vulnificus (Figure 6 ) grown in agar. A clear inhibition zone of $1.2 \pm 0.25 \mathrm{~cm}^{2}$ for the hexane extract was obtained in the $S$. aureus culture (Figure $5 \mathrm{a}$ ) and negative results were obtained when the hexane was added in the disk as a negative control (Figure 5b). When methanol extracts were tested, an inhibition area was clearly observed of $2.2 \pm 0.03 \mathrm{~cm}^{2}$ in the $S$. aureus culture (Figure $5 \mathrm{c}$ ) and again, negative inhibition was observed when the solvent was used. Results using water and dichloromethane extracts showed no visible antibacterial effect. The culture of $V$. vulnificus exposed to disks containing the methanol extracts showed a clear inhibition zone of $1.9 \pm 0.17 \mathrm{~cm}^{2}$ (Figure 6c). However, the hexane, dichloromethane and water extracts showed negative antibacterial effects. The calculated areas of inhibition are summarized in Table 1.
De acuerdo con nuestros resultados que se muestran en la Figura 4, la densidad máxima de células se observó alrededor del día 13 de cultivo.

\section{Actividad antibacteriana de extractos crudos}

El potencial antibacteriano de cada disolvente se evaluó por separado frente a las bacterias patógenas Gram positivas, S. aureus (Figure 5) y bacterias Gramnegativas, V. vulnificus (Figure 6) cultivadas en agar. En el cultivo de $S$. aureus se obtuvo una zona clara de inhibición de $1.2 \pm 0.25 \mathrm{~cm}^{2}$ para el extracto con hexano (Figura $5 \mathrm{a}$ ) y se obtuvieron resultados negativos cuando se añadió el hexano en el disco como control negativo (Figura 5b). Cuando se probaron los extractos de metanol, se observó claramente un área de inhibición de $2.2 \pm 0.03 \mathrm{~cm}^{2}$ en el cultivo de $S$. aureus (Figura 5c) y, de nuevo, se observó una inhibición negativa cuando se utilizó el disolvente. Los resultados con extractos de agua y diclorometano no mostraron ningún efecto antibacteriano visible. El cultivo de V. vulnificus expuesto a discos que contienen los extractos de metanol mostró una zona clara de inhibición de $1.9 \pm$ $0.17 \mathrm{~cm}^{2}$ (Figura 6c). Sin embargo, los extractos de hexano, diclorometano y agua mostraron efectos antibacterianos negativos. Las áreas de inhibición calculadas se resumen en la Tabla 1. 

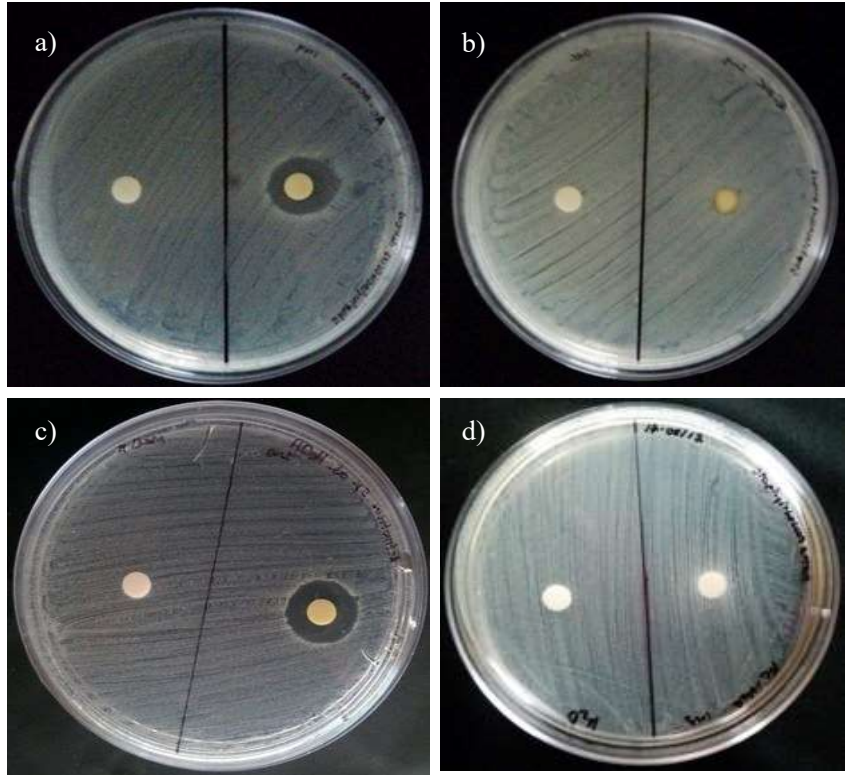

Figure 5. Disk diffusion test of $A$. octonarius Ehrenberg. Extracts against $S$. aureus: a) hexane extract; b) dichloromethane extract; c) methanol extract; d) water extract. Left disk = negative control (only solvent); Right disk $=1 \mathrm{mg}$ of extract.

Figura 5. Prueba de difusión de disco de A. octonarius Ehrenberg. Extractos contra S. aureus: a) extracto de hexano; b) extracto de diclorometano; c) extracto de metanol; d) extracto de agua. Disco izquierdo = control negativo (solo disolvente); Disco derecho $=1 \mathrm{mg}$ de extracto.
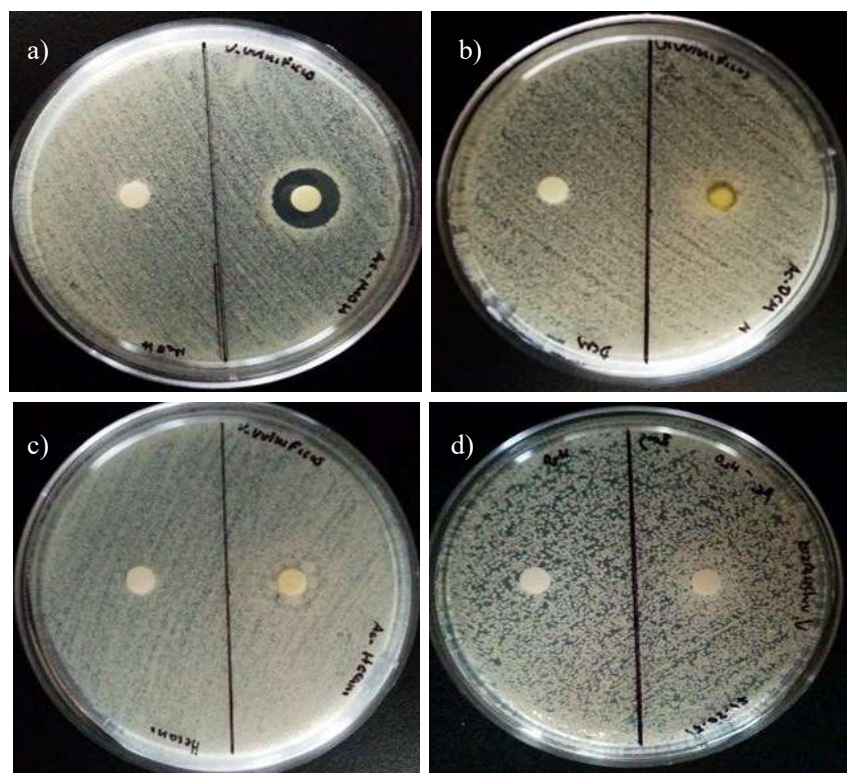

Figure 6. Disk diffusion method of $A$. octonarius Ehrenberg. Extracts against $V$. vulnificus: a) hexane extract; b) dichloromethane extract; c) methanol extract; d) water extract. Left disk = negative control (only solvent); Right disk $=1 \mathrm{mg}$ of extract.

Figura 6. Método de difusión en disco de A. octonarius Ehrenberg. Extractos contra V. vulnificus: a) extracto de hexano; b) extracto de diclorometano; c) extracto de metanol; d) extracto de agua. Disco izquierdo = control negativo (solo disolvente); Disco derecho $=1 \mathrm{mg}$ de extracto. 
Table 1.

Area of inhibition $\left(\mathrm{cm}^{2}\right)$ of the $A$. octonarius Ehrenberg extracts tested on strains $S$. aureus and $V$. vulnificus using the disk diffusion test. (mean $\pm S E, n=3$ ).

Tabla 1.

Área de inhibición $\left(\mathrm{cm}^{2}\right)$ de los extractos de $A$. octonarius Ehrenberg analizados en las cepas $S$. aureus y $V$. vulnificus utilizando la prueba de difusión en disco. (media $\pm S E, n=3$ ).

\begin{tabular}{ccc}
\hline Diatom extracts & \multicolumn{2}{c}{ Area of inhibition $\left.\mathbf{( c m}^{2}\right)$} \\
\cline { 2 - 3 }$(1 \mathrm{mg}$ of dry wt. of cells) & Staphylococcus aureus & Vibrio vulnificus \\
\hline Hexane & $1.2 \pm 0.25$ & - \\
Dichloromethane & - & - \\
Methanol & $2.2 \pm 0.03$ & $1.9 \pm 0.17$ \\
Water & - & - \\
\hline
\end{tabular}

\section{Discussion}

As of today, there is no published data, in scientific journals, showing the presence of $A$. octonarius species on the coasts of the Manzanillo (Mexico) and the morphological descriptions available for the Actinoptychus species are scarce and lacking highresolution details. The microscopic morphology observed in the diatom specie described in this study agrees with the features of the $A$. octonarius species reported by Ehrenberg in the year 1844 (Lavigne \& Guiry, 2018b). A. octonarius has been described as having an internal leaflet covered by radially organized pores, a hyaline area in the center containing pores (areoles), labiate processes around the cell border, and presence of a hole called pseudonodule, a key feature that differentiates this diatom from other species. However, we additionally observe that the labiates processes vary in number in the same samples studied, we propose that this characteristic varies according to age, the younger the diatom the less quantity of labiates processes. Our images show that $A$. octonarius Ehrenberg complies with the basic morphology of a benthic diatom with radial organization and in the center the annular ring. It is worth noting that, the species $A$. octonarius Ehrenberg described in this study differ from the diatoms of the genus Actinoptychus identified on the coast of Oaxaca, Mexico. These diatoms ( $A$. splendens, A. vulgaris, A. concentricus, A. aster and $A$. senarius) are characterized in that the valves have a radial areolar field sectioned into pentagonal and hexagonal shapes, and all share a hyaline center without pores (Woolrich-Arrioja et al., 2019). The

\section{Discusión}

Al día de hoy, no existen datos, publicados en revistas científicas, que muestren la presencia de la especie $A$. octonarius en las costas del Manzanillo (México) y las descripciones morfológicas disponibles para la especie Actinoptychus son escasas y carecen de detalles de alta resolución. La morfología microscópica observada en la especie de diatomeas descrita en este estudio concuerda con las características de la especie A. octonarius reportadas por Ehrenberg en el año 1844 (Lavigne \& Guiry, 2018b). Se ha descrito que $A$. octonarius tiene una valva interna cubierta por poros organizados radialmente, un área hialina en el centro que contiene poros (areolas), procesos labiados alrededor del borde celular y la presencia de un orificio llamado pseudonodulus, una característica clave que diferencia a esta diatomea de otras especies. Sin embargo, adicionalmente observamos que los procesos labiados varían en número en las mismas muestras estudiadas, proponemos que esta característica varía según la edad, cuanto más joven es la diatomea menor cantidad de procesos labiados. Nuestras imágenes muestran que $A$. octonarius Ehrenberg cumple con la morfología básica de una diatomea bentónica con organización radial y en el centro el anillo anular. Cabe señalar que la especie A. octonarius Ehrenberg descrita en este estudio difiere de las diatomeas del género Actinoptychus identificadas en la costa de Oaxaca, México. Estas diatomeas ( $A$. splendens, A. vulgaris, A. concentricus, A. aster y $A$. senarius) se caracterizan porque las valvas tienen un campo areolar radial seccionado en formas pentagonales $y$ hexagonales, y todas comparten un centro hialino sin 
possibility that $A$. octonarius Ehrenberg is also located in another region of the Mexican Pacific coast is not ruled out (López-Fuerte \& Siqueiros-Beltrones, 2006; López-Fuerte et al., 2015; Siqueiros-Beltrones et al., 2017; Woolrich-Arrioja et al., 2019).

On the other hand, it is known that most antibiotics are isolated from terrestrial organisms and plants (Drews, 2000). New antimicrobial agents extracted from marine organisms could serve against pathogen bacteria that negatively affect humans, animals, and agriculture. It is well known that marine phytoplankton are sessile and hold soft bodies, they evolutionarily developed chemical strategies to escape predators present in their natural habitat and defend against many potentially harmful bacteria, fungi, parasites, and viruses (Pančić \& Kiørboe, 2018; Clucas, 2019). These dissuasive chemicals may contain valuable molecules with antibacterial activity with the potential to treat infections caused by bacteria (Liu, 2012; Gribble, 2015; Mayer et al., 2017; Tortorella et al., 2018). There are several studies where crude extracts of diatoms leached by organic solvents have been shown to inhibit the growth of bacteria in vitro (Kellam \& Walker, 1989; Binea et al., 2009; Desbois et al., 2009; Bhatnagar \& Kim, 2010).

Applying the disk diffusion method, to find the sensitivity of the extracts against bacteria, our results show that the methanol extract of $A$. octonarius Ehrenberg inhibited the growth of $S$. aureus (Gram-positive) and $V$. vulnificus (Gram-negative). While the crude extract with hexane only inhibited the growth of $S$. aureus. Also, it is important to mention that the crude diatom extracts from this study contains a diverse number of molecules at different concentration. From the cited literature, the bioactive compounds could be different types of molecules including isoprenoids, polysaccharides, fatty acids, terpenes among others (Belt et al.,2003; Massé et al., 2004; Desbois \& Smith, 2010; De Jesus Raposo et al., 2015; Athanasakoglou \& Kampranis, 2019).

\section{Conclusion}

This study revealed, for the first time, morphological characteristics of A.octonarius Ehrenberg diatom through a SEM methodology. Furthermore, it poros (Woolrich-Arrioja et al., 2019). No se descarta la posibilidad de que $A$. octonarius Ehrenberg también esté ubicado en otra región de la costa del Pacífico mexicano (López-Fuerte \& Siqueiros-Beltrones, 2006; LópezFuerte et al., 2015; Siqueiros-Beltrones et al., 2017; Woolrich-Arrioja et al., 2019).

Por otro lado, se sabe que la mayoría de los antibióticos se aíslan de organismos y plantas terrestres (Drews, 2000). Nuevos agentes antimicrobianos extraídos a partir de organismos marinos podrían servir contra las bacterias patógenas que afectan negativamente a los seres humanos, los animales y a la agricultura. Es bien sabido que, el fitoplancton marino es sésil y tiene cuerpos blandos, que evolutivamente desarrollaron estrategias químicas para escapar de los depredadores presentes en su hábitat natural y defenderse de muchas bacterias, hongos, parásitos y virus potencialmente dañinos (Pančić \& Kiørboe, 2018; Clucas, 2019). Estos productos químicos disuasorios pueden contener moléculas valiosas con actividad antibacteriana con potencial para tratar infecciones causadas por bacterias (Liu, 2012; Gribble, 2015; Mayer et al., 2017; Tortorella et al., 2018). Hay varios estudios en los que se ha demostrado que los extractos crudos de diatomeas lixiviados por disolventes orgánicos inhiben el crecimiento de bacterias in vitro (Kellam \& Walker, 1989; Binea et al., 2009; Desbois et al., 2009; Bhatnagar \& Kim, 2010).

Aplicando el método de difusión en disco, para encontrar la sensibilidad de los extractos frente a bacterias, nuestros resultados muestran que el extracto metanólico de $A$. octonarius Ehrenberg inhibió el crecimiento de $S$. aureus (Gram-positivos) y V. vulnificus (Gram-negativo). Mientras que el extracto crudo con hexano solo inhibió el crecimiento de $S$. aureus. Además, es importante mencionar que los extractos crudos de diatomeas de este estudio contiene un número diverso de moléculas a diferentes concentraciones. De la literatura citada, los compuestos bioactivos podrían ser diferentes tipos de moléculas incluyendo isoprenoides, polisacáridos, ácidos grasos, terpenos entre otros (Belt et al., 2003; Massé et al., 2004; Desbois \& Smith, 2010; De Jesus Raposo et al., 2015; Athanasakoglou \& Kampranis, 2019).

\section{Conclusión}

Este estudio reveló por primera vez características morfológicas de la diatomea de A. octonarius Ehrenberg 
was observed that molecules present in the methanolic extracts of Actinoptychus octonarius Ehrenberg have antibacterial action against Gram-positive $S$. aureus and Gram-negative $V$. vulnificus, while the hexane extract showed effect only against $V$. vulnificus. Considering these facts, $A$. octonarius Ehrenberg may be a source of antibacterial compounds. However, further studies must be performed, aiming at the identification of the bioactive molecules, and also evaluating the safety and efficacy of crude extracts for a possible pharmaceutical use.

\section{Acknowledgments}

The authors thank J. Reyes-Gomez and D. Pozas-Zepeda for their assistance with the SEM and Laura Valdez-Velázquez for loaning her laboratory equipment during the development of this project. This study was supported by a Consejo Nacional de Ciencia y Tecnologia scholarship to M. Sc. Rocio Zatarain-Palacios. a través de una metodología SEM. Además, se observó que las moléculas presentes en los extractos metanólicos de Actinoptychus octonarius Ehrenberg tienen acción antibacteriana contra S. aureus Gram-positivos y V. vulnificus Gram-negativos. Mientras que el extracto de hexano mostró efecto solo contra $V$. vulnificus. Teniendo en cuenta estos hechos, $A$. octonarius Ehrenberg podría ser una fuente de compuestos antibacterianos. Sin embargo, se deben realizar estudios, con el objetivo de identificar las moléculas bioactivas, y también evaluar la seguridad y eficacia de los extractos crudos para un posible uso farmacéutico.

\section{Agradecimientos}

Los autores agradecen a J. Reyes-Gomez y D. Pozas-Zepeda por su ayuda con el SEM y a Laura ValdezVelázquez por prestar su equipo de laboratorio durante el desarrollo de este proyecto. Este estudio fue apoyado por una beca del Consejo Nacional de Ciencia y Tecnología para M. Sc. Rocio Zatarain-Palacios.

\section{References}

Athanasakoglou, A. \& Kampranis, S. C. (2019). Diatom isoprenoids: Advances and biotechnological potential. Biotechnology Advances, 37(8): 107417 https://doi.org/10.1016/j.biotechadv.2019.107417

Belt, S. T., Massé, G., Allard, W. G., Robert, J. M. and Rowland, S. J. (2003). Novel monocyclic sester- and triterpenoids from the marine diatom, Rhizosolenia setigera. Tetrahedron Letters, 44(51): 9103-9106. https://doi.org/10.1016/j. tetlet.2003.10.039

Bhatnagar, I. \& Kim, S. K. (2010). Immense Essence of Excellence: Marine Microbial Bioactive Compounds. Mar. Drugs, 8 (10): 2673-2701. https://doi.org/10.3390/md8102673

Binea, H. K., Kassim, T. I. and Binea, A. K. (2009). ANTIBACTERIAL ACTIVITY OF DIATOM NITZSCHIA PALEA (KUETZ.) W. SM. EXTRACT. Iraqi J. Biotech, 8(2): 562-566. http://iasj.net/iasj?func=fulltext\&ald=89226

Blunt, J. W., Copp, B. R., Keyzers, R. A., Munro, M. H. G and Prinsep, M. R. (2015). Marine natural products. Nat. Prod. Rep., 32(2): 116-211. https://doi.org/10.1039/C4NP00144C

Blunt, J. W., Copp, B. R., Keyzers, R. A., Munro, M. H. G. and Prinsep, M. R. (2017). Marine natural products. Nat. Prod. Rep., 34(3): 235-294. https://doi.org/10.1039/C4NP00124F

Clinical and laboratory standards institute [CLSI]. (2006). Performance Standards for Antimicrobial Susceptibility Testing, Fifteenth Informational Supplement, Wayne, PA. USA.

Clucas, B. (2019). Defensive chemicals. Encyclopedia of Animal Behavior, 327-333. https://doi.org/10.1016/B978-0-12809633-8.01005-0

De Jesus Raposo, M. F., De Morais, A. M. B., De Morais, R. M. S. C. (2015). Marine Polysaccharides from Algae with Potential Biomedical Applications. Marine Drugs, 13(5):2967-3028. https://doi.org/10.3390/md13052967

De Morais, M. G., Vaz, B. Da S., De Morais, E. G. and Costa, J. A. V. (2015). Biologically Active Metabolites Synthesized by Microalgae. BioMed Research International, 1: 1-15. https://doi.org/10.1155/2015/835761

Desbois, A. P., Mearns-Spragg, A. and Smith, V. J. (2009). A fatty acid from the diatom Phaeodactylum tricornutum is antibacterial against diverse bacteria including multi-resistant Staphylococcus aureus (MRSA). Marine Biotechnology, 11(1): 45-52. https://doi.org/10.1007/s10126-008-9118-5 
Desbois, A. P. \& Smith, V. J. (2010). Antibacterial free fatty acids: Activities, mechanisms of action and biotechnological potential. Applied Microbiology and Biotechnology, 85: 1629-1642. https://doi.org/10.1007/s00253-009-2355-3

Desbois, A. P. \& Smith, V. J. (2015) Disk Diffusion Assay to Assess the Antimicrobial Activity of Marine Algal Extracts. In: Stengel D., Connan S. (eds) Natural Products From Marine Algae. Methods in Molecular Biology, vol 1308. Humana Press, New York, NY. https://doi.org/10.1007/978-1-4939-2684-8

Drews, J. (2000). Drug discovery: a historical perspective. Science, 287(5460): 1960-1964. https://doi.org/10.1126/ science.287.5460.1960

Garcia-Argaez, A. N., Apan, T. O. R., Delgado, H. P., Velázquez, G. and Martínez-Vázquez, M. (2000). Anti-inflammatory activity of coumarins from Decatropis bicolor on TPA ear mice model. Planta medica, 66(3): 279-281. https://doi. org/10.1055/s-2000-14894

Gribble, G. W. (2015). Biological Activity of Recently Discovered Halogenated Marine Natural Products. Marine Drugs, 13(7): 4044-4136. https://doi.org/10.3390/md13074044

Guillard, R. R. L. \& Hargraves, P. E. (1993). Stichochrysis immobilis is a diatom, not a chrysophyte. Phycologia, 32(3): 234-236. https://doi.org/10.2216/i0031-8884-32-3-234.1

Hsu, W. Y., Wei, C. I. and Tamplin, M. L. (1998). Enhanced broth media for selective growth of Vibrio vulnificus. Applied and Environmental Microbiology, 64(7): 2701-2704. https://doi.org/10.1128/aem.64.7.2701-2704.1998

Kellam, S. J. \& Walker, J. M. (1989). Antibacterial Activity from Marine Microalgae in Laboratory Culture. Br. Phycol. J, 24 (2): 191-194. http://www.tandfonline.com/doi/pdf/10.1080/00071618900650181

Kaysner, C. A., De Paola, A. and Jones, J. (2004). Vibrio spp. In USFDA Bacteriological Analytical Manual (BAM). https:// www.fda.gov/food/laboratory-methods-food/bam-chapter-9-vibrio

Lavigne R. in Guiry, M. D. and Guiry, G. M. (2018a). AlgaeBase. World-wide electronic publication, National University of Ireland, Galway. http://www.algaebase.org

Lavigne R. in Guiry, M. D. and Guiry, G. M. (2018b). AlgaeBase. World-wide electronic publication. National University of Ireland, Galway. http://www.algaebase.org/search/species/detail/?species id=R086b77a994f714a6

Liu, Y. (2012). Renaissance of Marine Natural Product Drug Discovery and Development. Journal of Marine Science: Research \& Development, 02(02): 1-2. https://doi.org/10.4172/2155-9910.1000e106

López-Fuerte, F. O. \& Siqueiros-Beltrones, D.A. (2006). Distribución y estructura de comunidades de diatomeas en sedimentos de un sistema de manglar Structure and distribution of diatom communities in sediments of a mangrove system, 16(1): 23-33. http://www.scielo.org.mx/scielo.php?script=sci arttext\&pid=S0188-88972006000100003

López-Fuerte, F. O., Siqueiros-Beltrones, D. A. and Yabur, R. (2015). First record of benthic diatoms (Bacillariophyceae and Fragilariophyceae) from Isla Guadalupe, Baja California, Mexico. Revista Mexicana de Biodiversidad, 86(2): 281-292. https://doi.org/10.1016/j.rmb.2015.04.016

Lotz, M. J., Tamplin, M. L. and Rodrick, G. E. (1983). Thiosulfate-citrate-bile salts-sucrose agar and its selectivity for clinical and marine vibrio organisms. Annals of Clinical and Laboratory Science, 13(1): 45-48. http://www.annclinlabsci. org/content/13/1/45.full.pdf

Lundholm, N., Daugbjerg, N. and Moestrup, Ø. (2002). Phylogeny of the Bacillariaceae with emphasis on the genus Pseudonitzschia (Bacillariophyceae) based on partial LSU rDNA. European Journal of Phycology, 37(1): 115-134. https://doi.org/10.1017/S096702620100347X

Malve, H. (2016). Exploring the ocean for new drug developments: Marine pharmacology. Journal of Pharmacy \& Bioallied Sciences, 8(2): 83-91. https://doi.org/10.4103/0975-7406.171700

Massé, G., Belt, S. T., Rowland, S. J. and Rohmer, M. (2004). Isoprenoid biosynthesis in the diatoms Rhizosolenia setigera (Brightwell) and Haslea ostrearia (Simonsen). Proceedings of the National Academy of Sciences of the United States of America, 101(13): 4413-4418. https://doi.org/10.1073/pnas.0400902101

Mayer, A. M. S.; Rodríguez, A. D.; Taglialatela-Scafati, O. and Fusetani, N. (2017). Marine Pharmacology in 2012-2013: Marine Compounds with Antibacterial, Antidiabetic, Antifungal, Anti-Inflammatory, Antiprotozoal, Antituberculosis, and Antiviral Activities; Affecting the Immune and Nervous Systems, and Other Miscellaneous Mechanisms of Action. Mar. Drugs, 15 (9): 273. https://doi.org/10.3390/md15090273

Pančić, M. \& Kiørboe, T. (2018). Phytoplankton defence mechanisms: traits and trade-offs. Biological Reviews, 93(2): 12691303. https://doi.org/10.1111/brv.12395 
Rivera-Vilarelle, M., Quijano-Scheggia, S., Olivos-Ortiz, A., Gaviño-Rodríguez, J. H., Castro-Ochoa, F., and Reyes-Herrera, A. (2013). The genus Pseudo-nitzschia (Bacillariophyceae) in Manzanillo and Santiago Bays, Colima, Mexico. Botanica Marina, 56(4): 357-373. https://doi.org/10.1515/bot-2012-0176

Ross, R. \& Sims, P. A. (1972). The fine structure of the frustule in centric diatoms: A suggested terminology. British Phycological Journal, 7(2): 139-163. https://doi.org/10.1080/00071617200650171

Round, F. E. (Frank E., Crawford, R. M. and Mann, D. G. (1990). The Diatoms. Biology and Morphology of the Genera. Cambridge University Press.

Siqueiros-Beltrones, D. A., Argumedo-Hernández, U. and López-Fuerte, F. O. (2017). Diversity of benthic diatoms in the Guerrero Negro Lagoon (El Vizcaíno Biosfere Reserve), Baja California Peninsula, Mexico. Revista Mexicana de Biodiversidad, 88 (1): 21-35. https://doi.org/10.1016/j.rmb.2017.01.026

Stonik, V. \& Stonik, I. (2015). Low-Molecular-Weight Metabolites from Diatoms: Structures, Biological Roles and Biosynthesis. Mar. Drugs, 13 (6): 3672-3709. https://doi.org/10.3390/md13063672

Tortorella, E., Tedesco, P., Palma Esposito, F., Garren January, G., Fani, R., Jaspars, M. and de Pascale, D. (2018). Antibiotics from Deep-Sea Microorganisms: Current Discoveries and Perspectives. Marine drugs, 16(10), 355. https://doi.org/10.3390/md16100355

Vandepitte, J., Verhaegen, J., Engbaek, K. and Rohner, P. (2003). Basic laboratory procedures in clinical bacteriology. https://books.google.com.mx/books?hl=en\&lr=\&id=UHYODgAAQBAJ\&oi=fnd\&pg=PR5\&dq=Basic+Laboratory +Procedures+in+Clinical+Bacteriology+scholar\&ots=dBa9Mph9wJ\&sig=Q0RAKRiz-mCZS7Wm13T91oHZLD8

Woolrich-Arrioja, A., Aké-Castillo, J. A. and Torres-Ariño, A. (2019). Descripción de especies de diatomeas del género Actinoptychus de la costa de Oaxaca, México. Acta Botanica Mexicana, (126). https://doi.org/10.21829/ abm126.2019.1460

World Health Organization (WHO). (2017). Global priority list of antibiotic-resistant bacteria to guide research, discovery, and development of new antibiotics. https://www.who.int/medicines/publications/global-priority-list-antibioticresistant-bacteria/en/

Zubair, M. S., Anam, S. and Lallo, S. (2016). Cytotoxic activity and phytochemical standardization of Lunasia amara Blanco wood extract. Asian Pacific Journal of Tropical Biomedicine, 6(11): 962-966. https://doi.org/10.1016/j. apjtb.2016.04.014 